A $\mathrm{C} G \quad$ Rec. Nat. Prod. 16:5 (2022) 463-470

records of natural products

\title{
A New Alkaloid from the Endophytic Fungus of Crocus sativus L.,
}

\section{Aspergillus fumigatus Y0107}

\author{
Yu Jiang $\oplus^{1}$, Chunxiao Jiang $\oplus^{2}$, Qi Zhou $\oplus^{2}$, Yingpeng Tong $\oplus^{2 *}$ \\ and Ping Wang ${ }^{1 *}$ \\ ${ }^{1}$ College of Pharmaceutical Sciences, Zhejiang University of Technology, Hangzhou, Zhejiang \\ 310014, P. R. China \\ ${ }^{2}$ Institute of Natural Medicine and Health Product, School of Advanced Study, Taizhou University, \\ Taizhou, Zhejiang 318000, P. R. China
}

(Received October 28, 2021; Revised January 31, 2022; Accepted February 02, 2022)

\begin{abstract}
A new alkaloid (compound 1), together with 8 known alkaloids (compounds 2-9), were isolated from Aspergillus fumigatus Y0107 extracts from the lateral buds of Crocus sativus Linn (saffron). The structure of compound 1 was elucidated with NMR spectroscopy, High-resolution electrospray ionization mass spectrometry (HR-ESI-MS) and compared with its analogues in the literatures. The antibacterial activities of the crude ethyl acetate (EA) extract (CEE) and isolated compounds (compounds 1, 2, 6, 8) were evaluated against plant pathogenic bacteria. Compound $\mathbf{2}$ and the CEE demonstrated moderate inhibitory activity with MICs of 100 $\mu \mathrm{g} / \mathrm{mL}$ against Erwinia sp.
\end{abstract}

Keywords: Crocus sativus L.; endophytic fungus; Aspergillus fumigatus Y0107; alkaloids; plant pathogenic bacteria. (C) 2022 ACG Publications. All rights reserved.

\section{Introduction}

Crocus sativus L. (saffron) is a flowering plant belonging to the Iridaceae family, and its dry stigma is a precious traditional Chinese Medicines with a long history of application. At present, more than 40 kinds of endophytic fungi have been isolated from different parts of Crocus sativus Linn, including Aspergillus, Alternaria, Penicillium, Trichoderma, Fusarium, Alternaria, Paecilomyces, Epicoccum, Mortierella, Hansfordia, Chaetomium, Rhizopus genus and so on [1-2]. To the best of our knowledge, only four studies have documented metabolites of endophytic fungi from $C$. sativus. Zheng, et al. [3] characterized (-)-(1R,4R)-1,4-(2,3)-indolmethane-1-methyl-2,4-dihydro-1 $H$-pyrazino-[2,1-b]-quinazoline-3,6-dione, a quinazoline alkaloid, from Penicillium vinaceum, an endophytic fungus isolated from C. sativus corm. Furthermore, phialomustin A-D with an azaphilone derived skeleton and a crocin with an unascertained structure were isolated from endophytic fungi, Phialophora mustea and

\footnotetext{
* Corresponding authors: E-Mail: wangping45@zjut.edu.cn (P. Wang) ; Phone/Fax: 0086-0571-88871076; fish166@tzc.edu.cn (Y.Tong); Phone/Fax: 0086-0576-88661988
} 


\section{A new alkaloid from Crocus sativus}

Fusarium sp., respectively [4-5]. In addition, Luo, et al. [6] extracted beauvericin, prolipyrone C and ergosta-5 $\alpha, 8 \alpha$-epidioxy-6,22-dien-3 $\beta$-ol from an undocumented endophytic fungus (CSL-13). However, there has been no reports on the novel secondary metabolites of Aspergillus genus endophytic fungi from the plant $C$. sativus so far.

Accordingly, in our ongoing work, with the chemical investigation of Aspergillus fumigatus Y0107 extract from Crocus sativus L., a new alkaloid (compound 1) together with 8 known alkaloids (2-9) (Figure 1) was isolated and structurally characterized. Importantly, compound $\mathbf{2}$ and CEE exhibited moderate inhibitory activity against plant pathogenic bacteria, Erwinia sp. In a nutshell, we isolated and elucidated the structure of a new alkaloid, and evaluated the bioactivity of several isolates from Aspergillus fumigatus Y0107. Herein, the isolation, structure elucidation and bioactivity assessment of the alkaloid compounds are described.

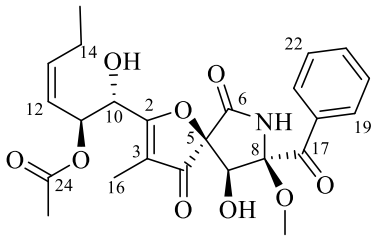

1<smiles>CC1=CN2C(=O)N3C(=O)C(n4cnc5ccccc5c4=O)CC(O)(c4ccccc43)C2(O)C1=O</smiles>

4

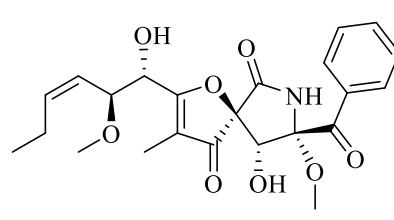

6

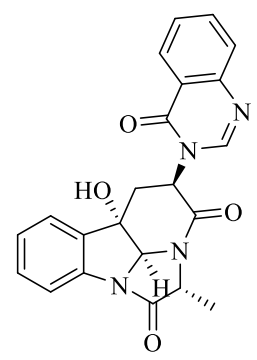

5

7
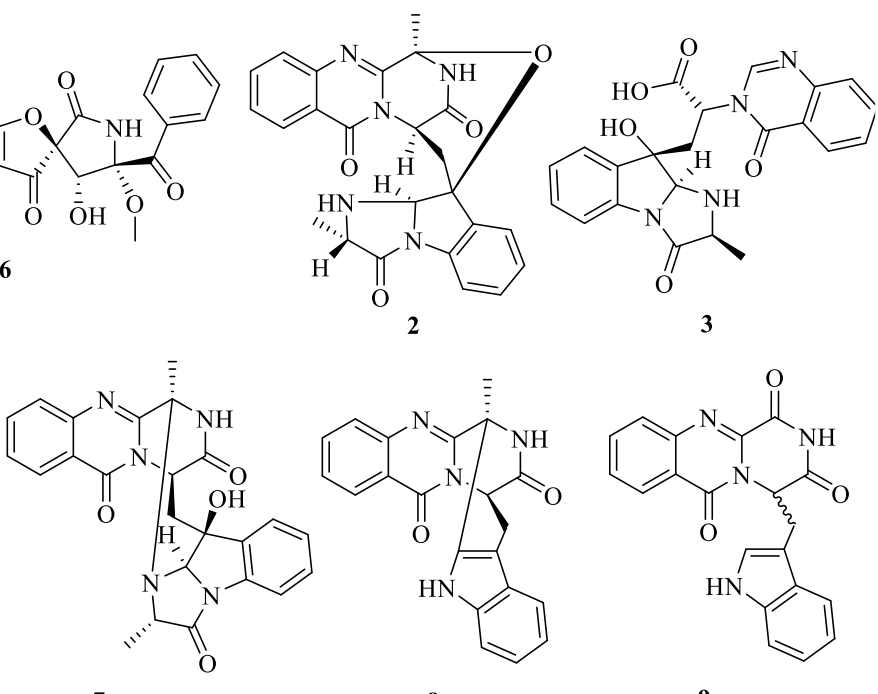

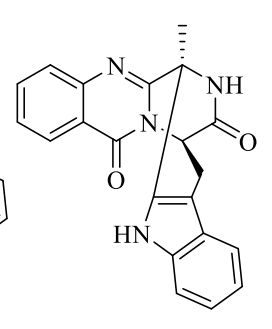

8<smiles>O=C1NC(=O)C(Cc2c[nH]c3ccccc23)n2c1nc1ccccc1c2=O</smiles>

Figure 1. Chemical structures of alkaloid compounds from Aspergillus fumigatus Y0107

\section{Materials and Methods}

\subsection{General Experimental Procedures}

The optical rotation was measured by a Jasco P-2000 digital polarimeter. The NMR spectra (including ${ }^{1} \mathrm{H}$ NMR, ${ }^{13} \mathrm{C}$ NMR, ${ }^{1} \mathrm{H}-{ }^{1} \mathrm{H}$ COSY, HSQC, and $\mathrm{HMBC}$ ) were recorded on a Bruker AVANCE III-400 spectrometer. The $77.160 \mathrm{ppm}$ and $7.260 \mathrm{ppm}$ resonances of $\mathrm{CDCl}_{3}$ and the 206.260 ppm and $2.050 \mathrm{ppm}$ resonances of acetone- $d_{6}$, were used as internal references to ascertain ${ }^{13} \mathrm{C}$ and ${ }^{1} \mathrm{H}$ chemical shifts, respectively. A Waters Synapt G2 type UHPLC-q-TOF mass spectrometer was used to obtain HR-ESI-MS data. Column chromatography (CC) was performed with silica gel (Qingdao Marine Chemical Co., Ltd, China) and Sephadex LH-20 (Pharmacia, Sweden), and thin layer chromatography was performed using silica gel 60 GF 254 (TLC, Qingdao Marine Chemical Co., Ltd, China). A reversed-phased C 18 column $(5 \mu \mathrm{m}, 10 \mathrm{~mm} \times 250 \mathrm{~mm}$, YMC-Pack ODS-A column) was used to carry out on an Agilent 1260 Infinity II HPLC (Aligent Technologies Inc., Germany).

\subsection{Fungal Material}

The endophytic fungus strain was isolated from lateral buds of Crocus sativus L. (purchased from Jiande Sandu Saffron Professional Cooperative) on May $7^{\text {th }}$, 2020, and stored in a $-80{ }^{\circ} \mathrm{C}$ cryopreservation box (ThermoFisher Scientific (China) Co. Ltd). Morphology analysis and 18S rRNA gene sequencing were performed to assign the strain as Aspergillus fumigatus (GenBank accession no. MZ854147) and named as Y0107. 


\subsection{Extraction and Isolation}

The seed culture with Aspergillus fumigatus Y0107 strains was cut into small pieces and inoculated into a solid medium (rice $120 \mathrm{~g}$ of $150 \mathrm{~mL}$ ultrapure water in $1 \mathrm{~L}$ erlenmeyer flask, 140 bottles) for stationary fermentation at $26{ }^{\circ} \mathrm{C}$ for 21 days. After cultivation, the crude extract $(182.1 \mathrm{~g})$ of the fermented rice medium was obtained by soaking ethyl acetate (EA, $18+4 \times 10$ L) overnight. The crude extract was dispersed into $2.5 \mathrm{~L}$ ultrapure water, and then extracted with $2 \mathrm{~L}$ petroleum ether (PE), EA, and $n$-butanol three times in turn. Then EA layers were collected and concentrated by vacuum to yield a crude EA extract (CEE, $49.3 \mathrm{~g}$ ).

The CEE was subjected to silica gel CC eluted with a gradient eluant of $\mathrm{CH}_{2} \mathrm{Cl}_{2} / \mathrm{EA}\left(\mathrm{CH}_{2} \mathrm{Cl}_{2}, 50: 1\right.$ to EA, v/v) and $\mathrm{CH}_{2} \mathrm{Cl}_{2} / \mathrm{MeOH}$ (10:1 to $\mathrm{MeOH}$ neat) to yield eleven fractions (Fr. 1 11). Fr. 4 (2.93 g) and Fr. 5 (1.66 g) were merged and eluted with different solvents to yield Fr. 45-1 (3.25 g). Moreover, the fraction was separated by silica gel CC (PE/EA, 2:1 to 1:1) to afford Fr. 45-1-1 45-1-5. Fr. 45-1-3 (975.2 mg) was separated by silica gel CC (PE/EA, 2:1), Sephadex LH-20 CC $\left(\mathrm{CH}_{2} \mathrm{Cl}_{2} / \mathrm{MeOH}, 1: 1\right)$, and repeated TLC (PE/EA, 1:1; $\left.\mathrm{CH}_{2} \mathrm{Cl}_{2} / \mathrm{MeOH}, 50: 1\right)$ to yield compound 2 (48.1 mg). Fr. 45-1-4 (724.4 mg) was subjected to silica gel $\mathrm{CC}\left(\mathrm{CH}_{2} \mathrm{Cl}_{2} / \mathrm{MeOH}, \mathrm{CH}_{2} \mathrm{Cl}_{2}\right.$ to 100:1) and Sephadex LH-20 CC $\left(\mathrm{CH}_{2} \mathrm{Cl}_{2} / \mathrm{MeOH}, 1: 1\right)$, and separated by semi-preparative $\mathrm{HPLC}\left(50 \% \mathrm{MeCN} / \mathrm{H}_{2} \mathrm{O}, \mathrm{v} / \mathrm{v}, 1.5 \mathrm{~mL} / \mathrm{min}\right)$ over a $\mathrm{C}_{18}$ column to obtain compound $3\left(1.8 \mathrm{mg}, t_{\mathrm{R}}=14.6 \mathrm{~min}\right)$. Fr. $45-1-5(561.1 \mathrm{mg})$ was purified by Sephadex LH-20 CC with $\mathrm{CH}_{2} \mathrm{Cl}_{2} / \mathrm{MeOH}(1: 1)$, silica gel $\mathrm{CC}$ with a gradient eluent of $\mathrm{CH}_{2} \mathrm{Cl}_{2} / \mathrm{EA}$ $\left(\mathrm{CH}_{2} \mathrm{Cl}_{2}, 10: 1\right.$ to $\left.1: 1\right)$, and repeated TLC (PE/EA, 1:2 and 1:4, respectively) to harvest compound 4 (18.9 mg).Fr. 6 (2.16 g) was subjected to silica gel CC, eluted with PE/EA (2:1 to EA neat) and Sephadex LH-20 CC with $\mathrm{CH}_{2} \mathrm{Cl}_{2} / \mathrm{MeOH}$ (1:1) to obtain 13 fractions (Fr. 6-4-1 6-4-4, Fr. 6-5-1 6-54, Fr. 6-6-1 6-6-5). Fr. 6-4-3 (244.2 mg) was separated via silica gel $\mathrm{CC}\left(\mathrm{CH}_{2} \mathrm{Cl}_{2} / \mathrm{MeOH}, 50: 1\right.$ to 1:1), TLC (PE/EA, 1:1) and semi-preparative HPLC $\left(60 \% \mathrm{MeCN}^{-} \mathrm{H}_{2} \mathrm{O}\right.$, v/v, $\left.1.5 \mathrm{~mL} / \mathrm{min}\right)$ to get compound $5\left(1.6 \mathrm{mg}, t_{\mathrm{R}}=21.6 \mathrm{~min}\right)$. Compounds $1\left(1.7 \mathrm{mg}, t_{\mathrm{R}}=21.1 \mathrm{~min}\right)$ and $\mathbf{6}\left(2.5 \mathrm{mg}, t_{\mathrm{R}}=25.5 \mathrm{~min}\right)$ were yielded from Fr. 6-5-3 (162.9 mg) by silica gel $\mathrm{CC}\left(\mathrm{CH}_{2} \mathrm{Cl}_{2} / \mathrm{MeOH}, \mathrm{CH}_{2} \mathrm{Cl}_{2}, 100: 1\right.$ to 10:1) and semipreparative $\mathrm{HPLC}\left(49 \% \mathrm{MeCN} / \mathrm{H}_{2} \mathrm{O}\right.$, v/v, $\left.1.5 \mathrm{~mL} / \mathrm{min}\right)$. Fr. 6-6-4 $(264.3 \mathrm{mg})$ was separated following silica gel $\mathrm{CC}\left(\mathrm{CH}_{2} \mathrm{Cl}_{2} / \mathrm{MeOH} \mathrm{CH} \mathrm{Cl}_{2}, 100: 1\right.$ to $2: 1$ ), and semi-preparative HPLC (45\% $\mathrm{MeCN} / \mathrm{H}_{2} \mathrm{O}$, $\mathrm{v} / \mathrm{v}, 1.5 \mathrm{~mL} / \mathrm{min})$ to afford compound $7\left(2.6 \mathrm{mg}, t_{\mathrm{R}}=19.5 \mathrm{~min}\right)$. Compounds $8\left(14.1 \mathrm{mg}, t_{\mathrm{R}}=14.7\right.$ $\left.\min , 60 \% \mathrm{MeCN} / \mathrm{H}_{2} \mathrm{O}, \mathrm{v} / \mathrm{v}, 1.5 \mathrm{~mL} / \mathrm{min}\right)$ and $9\left(5.2 \mathrm{mg}, t_{\mathrm{R}}=15.5 \mathrm{~min}, 50 \% \mathrm{MeCN} / \mathrm{H}_{2} \mathrm{O}, \mathrm{v} / \mathrm{v}, 1.5\right.$ $\mathrm{mL} / \mathrm{min})$ were purified by semi-preparative HPLC from Fr. 6-6-5 $(309.2 \mathrm{mg})$ after silica gel CC (PE/EA, 5:1 to EA neat).

11-Acetyl-pseurotin $A_{2}$ (1): White solid; $[\alpha]_{0}^{28}=-34.0$ ( $c$ 0.1, MeOH); HR-ESI-MS m/z $496.1582[\mathrm{M}+$ $\mathrm{Na}]^{+}$, calcd 496.1564 for $\mathrm{C}_{23} \mathrm{H}_{19} \mathrm{~N}_{5} \mathrm{O}_{4} \mathrm{Na} ;{ }^{1} \mathrm{H} \mathrm{NMR}\left(400 \mathrm{MHz}, \mathrm{TMS}, \mathrm{CDCl}_{3}\right)$ and ${ }^{13} \mathrm{C} \mathrm{NMR}(100 \mathrm{MHz}$, TMS, $\mathrm{CDCl}_{3}$ ) data see Table 1 .

\subsection{Antibacterial Bioassays}

The antibacterial activities of compounds $\mathbf{1}, \mathbf{2}, \mathbf{6}$ and $\mathbf{8}$, together with CEE, were determined based on a microbroth dilution method in 96-well culture plates according to the National Committee for Clinical Laboratory Standards [15-16]. The plant pathogenic bacteria, Agrobacterium tumefaciens, Pantoea agglomerans, Ralstonia solanacearum, Erwinia sp. were purchased from Ningbo testobio Co., Ltd, Zhejiang, China, and cultured in the NA nutrient medium (1 g yeast extract, $3 \mathrm{~g}$ beef extract, $5 \mathrm{~g}$ peptone, and $5 \mathrm{~g}$ glucose in $1 \mathrm{~L}$ sterile water, the $\mathrm{pH}$ was adjusted to 7.2 with $\mathrm{NaOH}$ ) [17]. Streptomycin (USP Grade, Sangon Biotech Co., Ltd, Shanghai, China), an antibacterial drug, was used as the positive control. The tested bacteria were placed in a constant temperature oscillation incubator (100 rpm) for $12 \mathrm{~h}$ at $30^{\circ} \mathrm{C}$. The NA nutrient broth was used to adjust the bacterial concentration to $1 \times 10^{5}-1 \times 10^{6} \mathrm{cfu} / \mathrm{mL}$ by observing the OD600 values of each bacterial dilution. The concentration of monomers, positive control and CEE initial solution in $\mathrm{DMSO} / \mathrm{H}_{2} \mathrm{O}$ was 200,200 and $400 \mu \mathrm{g} / \mathrm{mL}$, respectively. First of all, the diluted bacterial solution was added into each well of a 96 -well culture plate $(50 \mu \mathrm{L}$ per well). Then, the initial solution $(50 \mu \mathrm{L})$ was added into the first well and mixed evenly, from which $50 \mu \mathrm{L}$ of solution was transferred into the second well and mixed well following the two fold dilution method. Serial dilutions were repeated from the third to the twelfth well in triplicate. The minimal inhibitory concentrations (MIC) were determined after $24 \mathrm{~h}$ of incubation. 


\section{Results and Discussion}

\subsection{Structure Elucidation}

Compound 1 was isolated as a white solid and characterized as a dark spot under UV light at 254 $\mathrm{nm}$ and a brown spot after spraying with $10 \% \mathrm{H}_{2} \mathrm{SO}_{4}$ in $\mathrm{EtOH}$ with heating. Its molecular formula was determined to be $\mathrm{C}_{24} \mathrm{H}_{27} \mathrm{NO}_{9}$ from the $[\mathrm{M}+\mathrm{Na}]^{+}$ion at $\mathrm{m} / \mathrm{z} 496.1582$ (calculated 496.1564) in HRESI-MS, requiring 12 degrees of unsaturation.

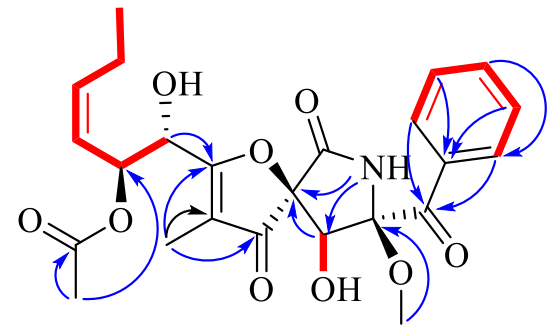

Figure 2. Key ${ }^{1} \mathrm{H}-{ }^{1} \mathrm{H}$ COSY and HBMC correlations of compound $\mathbf{1}$

The ${ }^{13} \mathrm{C}$ NMR/HSQC spectrum (Table 1), showed 24 carbon resonances, assigned to four electrophilic groups (two carbonyls at $\delta \mathrm{c} 197.8$ (C-4) and 194.5 (C-17), an ester group at $\delta \mathrm{c} 170.5$ (C24) and an acylamino at $\delta \mathrm{c} 165.2$ (C-6)), and four aromatic chemical shifts. Ten and four carbon signals were ascribed to $\mathrm{sp}^{3}$ and $\mathrm{sp}^{2}$ hybridized carbon atoms, respectively. The ${ }^{1} \mathrm{H}$ NMR spectroscopy (Table 1) revealed one oxymethyl and three methyl groups. The heteronuclear single quantum correlation (HSQC) is a powerful sequence widely used to correlate ${ }^{1} \mathrm{H}$ nuclei one-bond coupled with ${ }^{13} \mathrm{C}$ nuclei. The ${ }^{1} \mathrm{H}$ NMR and HSQC spectra and distortionless enhancement by polarization transfer (DEPT)-135 displayed signals of three oxygenated methines $\left(\delta_{\mathrm{H}} 5.80, \mathrm{H}-11 ; 4.77, \mathrm{H}-10 ; 4.62, \mathrm{H}-9\right)$, one methylene $\left(\delta_{\mathrm{H}} 2.26, \mathrm{H}_{\mathrm{a}}-14 ; 2.15, \mathrm{H}_{\mathrm{b}}-14\right)$, two exchangeable protons $\left(\delta_{\mathrm{H}} 7.38, \mathrm{NH} ; 4.03,9-\mathrm{OH}\right)$, as well as two olefinic protons $\left(\delta_{\mathrm{H}} 5.75, \mathrm{H}-13 ; 5.38, \mathrm{H}-12\right)$, according to their chemical shifts. The five aromatic protons $\left(\delta_{\mathrm{H}} 8.28, \mathrm{~d}, J=7.2 \mathrm{~Hz}, \mathrm{H}-23, \mathrm{H}-19 ; 7.64, \mathrm{t}, J=7.6 \mathrm{~Hz}, \mathrm{H}-21 ; 7.49, \mathrm{~d}, J=8 \mathrm{~Hz}, \mathrm{H}-\right.$ $22, \mathrm{H}-20)$ were identified as mono substituted benzene protons according to the typical coupling constants, number of split peaks and ${ }^{1} \mathrm{H}-{ }^{1} \mathrm{H}$ chemical shift correlation spectroscopy (COSY) correlations (H-19/H-20/H-21/H-22/H-23), as seen in Figure 2.

Except the aromatic protons of mono substituted benzene, ${ }^{1}{ }^{\mathrm{H}}-{ }^{1} \mathrm{H}$ COSY revealed the two protonproton spin systems of $\mathrm{H}-10 / \mathrm{H}-11 / \mathrm{H}-12 / \mathrm{H}-13 / \mathrm{H}-14 / \mathrm{H}-15$ and $\mathrm{H}-9 / 9-\mathrm{OH}$ (Figure 2). HMBC (Figure 2) confirmed the correlation of C-18 with $\mathrm{H}-20$ and $\mathrm{H}-22$, and $\mathrm{C}-17$ with $\mathrm{H}-19$ and $\mathrm{H}-23$, indicating that a carbonyl was connected to a mono substituted benzene. Furthermore, C-5 exhibited correlations to $\mathrm{H}-9$ and $\mathrm{NH}-7$, while $\mathrm{C}-9$ also correlated to $\mathrm{NH}-7$, suggesting that there was a $\mathrm{N}$-containing fivemembered heterocyclic ring in compound 1. The correlations between $\mathrm{H}-16$ and $\mathrm{C}-2, \mathrm{C}-3$ and $\mathrm{C}-4$ uncovered the position of $\mathrm{CH}_{3}-16$, while protons of oxymethyl that correlated to $\mathrm{C}-8$, revealed the position of the oxymethyl group. Moreover, $\mathrm{H}-25$ exhibited correlations with C-24 and C-11, while $\mathrm{H}$ 11 was correlated to $\mathrm{C}-24$, which indicated the position $\mathrm{C}-24$ and $\mathrm{CH}_{3}-25$. And the correlation between $\mathrm{H}-10$ and $\mathrm{C}-2$ displayed the connection of $\mathrm{C}-2$ and $\mathrm{C}-10$. The presence of a cis double bond was confirmed by the typical $J$ coupling constant of $10 \mathrm{~Hz}$ at $\mathrm{H}-12$. The above data further established the planar structure of compound 1, possessing a 1-oxa-7-azaspiro[4.4]non-2-ene-4,6-dione skeleton.

The ${ }^{1} \mathrm{H}$ NMR data of compound 1, pseurotin $\mathrm{A}_{2}$ (2011) [18], pseurotin $\mathrm{A}_{2}$ (2016) [18] and pseurotin A [19] were seen in Table S1. The NMR chemical shifts of compound 1 and pseurotin $A_{2}$ (2011) were more similar than that of the other two compounds. The chemical shift of 7-NH $\left(\delta_{\mathrm{H}} 7.38\right)$ in compound 1 was close to pseurotin $\mathrm{A}_{2}$ (2011), which might indicate the configuration of C-8 was same as that of pseurotin $A_{2}$ (2011). While their chemical shifts of 9-OH were all strongly shielded, the reason of which might be instrument effect. When compared with chemical shifts of pseurotin $A_{2}$ [18], the deshielded chemical shift $(\Delta \delta=1.10 \mathrm{ppm}$, Table S1) of H-11 indicated that the acetyl group moiety was located at $11-\mathrm{OH}$, consistent with HMBC cross peaks. And the chemical shift $(\Delta \delta=0.22 \mathrm{ppm})$ of $\mathrm{H}-10$ was also deshielded due to the long-range correlations. Thus, it could be considered that the difference between compound 1 and pseurotin $\mathrm{A}_{2}$ was the 11-position $\left({ }^{11} \mathrm{CH}\left(\mathrm{CH}_{3} \mathrm{COO}\right)\right.$ - in compound $\mathbf{1}$ and $-{ }^{11} \mathrm{CH}(\mathrm{OH})$ - in pseurotin $\left.\mathrm{A}_{2}\right)$. In the meantime, compound $\mathbf{1}$ had the exactly same chiral carbon 
in the same positions $(\mathrm{C}-5, \mathrm{C}-8, \mathrm{C}-9, \mathrm{C}-10$ and $\mathrm{C}-11)$ with pseurotin $\mathrm{A}_{2}$, and the optical rotation value of compound $1\left([\alpha]_{\mathrm{D}}^{28}-34.0(c 0.1, \mathrm{MeOH})\right)$ was closed to that of pseurotin $\mathrm{A}_{2}\left([\alpha]_{\mathrm{D}}{ }^{23}-30.6(\mathrm{c} 0.1\right.$, $\mathrm{MeOH})$ ) [20]. Accordingly, we found that compound 1 possessed the same absolute configuration as pseurotin $\mathrm{A}_{2}$, the absolute configuration of which had been previously determined $(5 S, 8 R, 9 S, 10 S$, $11 S$ ) by ECD analysis and was named 11-acetyl-pseurotin $\mathrm{A}_{2}$.

Table 1. NMR spectral data for compound 1 in $\mathrm{CDCl}_{3}$

\begin{tabular}{|c|c|c|c|}
\hline Position & $\delta_{\mathrm{H}}(\text { mult., } J \text { in } \mathbf{H z})^{\mathrm{a}}$ & $\delta \mathrm{c}^{\mathrm{b}}$ & HMBC $\left(\mathrm{H \# \rightarrow C \# )^{ \textrm {c } }}\right.$ \\
\hline 2 & & 185.1 & \\
\hline 3 & & 113.6 & \\
\hline 4 & & 197.8 & \\
\hline 5 & & 91.9 & \\
\hline 6 & & 165.2 & \\
\hline 7-NH & $7.38(\mathrm{~s})$ & & 5,9 \\
\hline 8 & & 89.7 & \\
\hline 9 & $4.62(\mathrm{~d}, 11.2)$ & 74.0 & 5 \\
\hline 10 & $4.77(\mathrm{~d}, 5.6)$ & 70.7 & 2,13 \\
\hline 11 & $5.80(\mathrm{~m})$ & 71.1 & 24 \\
\hline 12 & $5.38(\mathrm{t}, 10)$ & 122.3 & \\
\hline 13 & $5.75(\mathrm{~m})$ & 140.2 & \\
\hline 14 & $2.26(\mathrm{~m}), 2.15(\mathrm{~m})$ & 21.6 & \\
\hline 15 & $0.97(\mathrm{t}, 7.6)$ & 14.1 & 13,14 \\
\hline 16 & $1.80(\mathrm{~s})$ & 5.8 & $2,3,4$ \\
\hline 17 & & 194.5 & \\
\hline 18 & & 132.5 & \\
\hline $19 / 23$ & $8.28(\mathrm{~d}, 7.2)$ & 130.7 & $23,21,17$ \\
\hline $20 / 22$ & $7.48(t, 8.0)$ & 128.9 & 18,22 \\
\hline 21 & 7.64 (t. 7.6) & 134.8 & 19 \\
\hline 24 & & 170.5 & \\
\hline 25 & $2.04(\mathrm{~s})$ & 21.2 & 24,11 \\
\hline 8-OMe & $3.38(\mathrm{~s})$ & 51.8 & 8 \\
\hline $9-\mathrm{OH}$ & $4.03(\mathrm{~d}, 12.4)$ & & \\
\hline
\end{tabular}

a Recorded at 400MHz. ${ }^{\mathrm{b}}$ Recorded at $100 \mathrm{MHz} .{ }^{\mathrm{c}}$ Recorded at $400 \mathrm{MHz}\left({ }^{1} \mathrm{H}\right.$ dimension), showing the correlations of protons with indicated carbon.

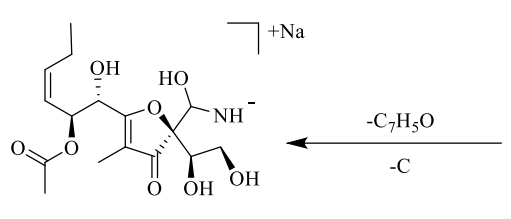

$\mathrm{m} / \mathrm{z} 381$<smiles>CC/C=C\[C@H](OC(C)=O)[C@@H](O)C1=C(C)C(=O)[C@@]2(C=NC(=O)C2O)O1</smiles>

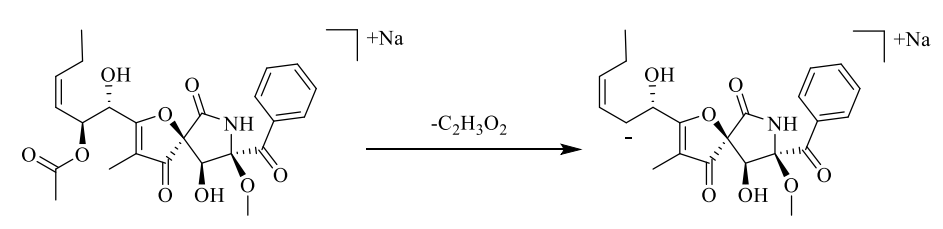

$\mathrm{m} / \mathrm{z} 496.1582$

$\mathrm{m} / \mathrm{z} 437$

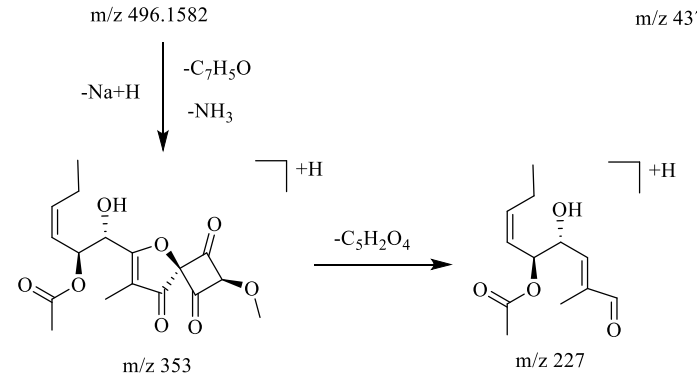

Figure 3. Proposed fragmentation pathways of positive ions for compound $\mathbf{1}$ 


\section{A new alkaloid from Crocus sativus}

The MS/MS fragmentation pathways of $[\mathrm{M}+\mathrm{Na}]^{+}$and $[\mathrm{M}+\mathrm{H}]^{+}$ions for compound $\mathbf{1}$ were suggested in Figure 3. Under collision voltage of mass spectrum, various characteristic ions were formed from compound 1 owing to the successive losses of $\mathrm{CH}_{3} \mathrm{COOH}, \mathrm{H}_{2} \mathrm{O}, \mathrm{H}_{2}, \mathrm{NH}_{3}, \mathrm{CO}$ and/or $\mathrm{C}_{6} \mathrm{H}_{6}$ molecules. The dissociation processes included de-esterification $\left(\mathrm{m} / z, 437\left[\mathrm{M}+\mathrm{Na}-\mathrm{C}_{2} \mathrm{H}_{3} \mathrm{O}_{2}\right]\right)$, decarbonization $(\mathrm{m} / \mathrm{z}$ $\left.381\left[\mathrm{M}+\mathrm{Na}-\mathrm{C}_{7} \mathrm{H}_{5} \mathrm{O}-\mathrm{C}\right]\right)$, dehydrogenation, dehydration $\left(\mathrm{m} / z \quad 360 \quad\left[\mathrm{M}+\mathrm{Na}-\mathrm{C}_{7} \mathrm{H}_{5} \mathrm{O}-\mathrm{C}-\mathrm{H}_{2}-\mathrm{H}_{2} \mathrm{O}\right]\right)$, deamination $\left(\mathrm{m} / z \quad 353\left[\mathrm{M}+\mathrm{H}-\mathrm{C}_{7} \mathrm{H}_{5} \mathrm{O}-\mathrm{NH}_{3}\right]\right)$ and decarbonylation $\left(\mathrm{m} / z \quad 227 \quad\left[\mathrm{M}+\mathrm{H}-\mathrm{C}_{7} \mathrm{H}_{5} \mathrm{O}-\mathrm{NH}_{3}-\right.\right.$ $\left.\mathrm{C}_{5} \mathrm{H}_{2} \mathrm{O}_{4}\right]$ ) (seen in Figure $\mathrm{S} 1$ ).

The eight documented alkaloid compounds were identified to be 18-epi-fumiquinazolin C (2) [7], fumigatoside $\mathrm{F}$ (3) [8], chaetominine (4) [9], (-)-11-epi-chaetominine (5) [10-11], 11-Omethylpseurotin A (6) [12], 2'-epi-fumiquinazoline D (7) [7], fumiquinazoline $\mathbf{J}(\mathbf{8})$ [13], and oxoglyantrypine (9) [14] by spectroscopic methods comparison of NMR and MS data with that of compounds reported in the literatures.

\subsection{Antibacterial Activity}

Several isolated compounds and CEE were tested for antibacterial activity against plant pathogenic bacteria. As shown in Table 2, compound 2 (MIC $100 \mu \mathrm{g} / \mathrm{mL}$ ) and CEE (MIC $100 \mu \mathrm{g} / \mathrm{mL}$ ) exhibited moderate antibacterial activity against Erwinia sp., which was weaker than the positive control (streptomycin, MIC $25 \mu \mathrm{g} / \mathrm{mL}$ ), while compounds $\mathbf{1}, \mathbf{6}$ and $\mathbf{8}$ showed no activity against this strain when their concentration range was within $100 \mu \mathrm{g} / \mathrm{mL}$. Unfortunately, none of the tested samples displayed inhibition against the strains, A. tumefaciens, $P$. agglomerans and $R$. solanacearum when their concentration range was within $100 \mu \mathrm{g} / \mathrm{mL}$, except the positive control.

Table 2. Antibacterial activity data of compounds $\mathbf{1 , 2 , 6 , 8}$ and CEE

\begin{tabular}{ccccc}
\hline \multirow{2}{*}{ Samples } & \multicolumn{4}{c}{ MIC $(\boldsymbol{\mu g} / \mathbf{m L})$} \\
\cline { 2 - 5 } $\mathbf{1}$ & A. tumefaciens & $\boldsymbol{P .}$ agglomerans & $\boldsymbol{R}$. solanacearum & Erwinia sp. \\
$\mathbf{2}$ & $>100$ & $>100$ & $>100$ & $>100$ \\
$\mathbf{6}$ & $>100$ & $>100$ & $>100$ & 100 \\
$\mathbf{8}$ & $>100$ & $>100$ & $>100$ & $>100$ \\
CEE & $>100$ & $>100$ & $>100$ & $>100$ \\
streptomycin & $>100$ & $>100$ & $>100$ & 100 \\
\hline
\end{tabular}

\section{Conclusions}

In this work, a new alkaloid compound, namely 11-acetyl-pseurotin $\mathrm{A}_{2}(\mathbf{1})$ together with eight known alkaloids were isolated from CEE of Aspergillus fumigatus Y0107, an endophytic fungus of the lateral buds of Crocus sativus Linn. The structure of compound $\mathbf{1}$ was elucidated with various spectroscopies, HR-ESI-MS analysis and comparison with its analogues in the literatures. Among them, compound $\mathbf{2}$ and CEE displayed antimicrobial activities against Erwinia sp., while no significant effects against the other three plant pathogenic bacteria were observed when their concentration range was within $100 \mu \mathrm{g} / \mathrm{mL}$. Additionally, compounds $\mathbf{1 ,} 6$ and $\mathbf{8}$ showed no markedly inhibition against the abovementioned plant pathogenic bacteria when their concentration range was within $100 \mu \mathrm{g} / \mathrm{mL}$.

\section{Acknowledgments}

This work was partially supported by the Key Special Projects of Intergovernmental International Science and Technology Innovation Cooperation (2017YFE0130100) and Natural Science Foundation of China (81703688).

\section{Supporting Information}

Supporting information accompanies this paper on http://www.acgpubs.org/journal/records-ofnatural-products 


\section{ORCID}

Yu Jiang: 0000-0002-2078-7539

Chunxiao Jiang: 0000-0001-9032-011X

Qi Zhou: 0000-0001-9082-6946

Yingpeng Tong: 0000-0002-6643-1132

Ping Wang: 0000-0002-6716-4451

\section{References}

[1] Z. A. Wani, D. N. Mirza, P. Arora and S. Riyaz-Ul-Hassan (2016). Molecular phylogeny, diversity, community structure, and plant growth promoting properties of fungal endophytes associated with the corms of saffron plant: An insight into the microbiome of Crocus sativus Linn, Fungal Biol-UK. 120, 1509-1524.

[2] I. Chamkhi, L. Sbabou and J. Aurag (2018). Endophytic fungi isolated from Crocus sativus L. (saffron) as a source of bioactive secondary metabolites, Phcog. J. 10, 1143-1148.

[3] C. J. Zheng, L. Li, J. P. Zou, T. Han and L. P. Qin (2012). Identification of a quinazoline alkaloid produced by Penicillium vinaceum, an endophytic fungus from Crocus sativus, Pharm. Biol. 50, 129133.

[4] Y. Nalli, D. N. Mirza, Z. A. Wani, B. Wadhwa, F. A. Mallik, C. Raina, A. Chaubey, S. Riyaz-Ul-Hassan and A. Ali (2015). Phialomustin A-D, new antimicrobial and cytotoxic metabolites from an endophytic fungus, Phialophora mustea, RSC Adv. 5, 95307-95312.

[5] P. Raj, S. S. Khan, M. Modak and D. Chauhan (2015). Cytotoxic activity of secondary metabolite produced by endophytic fungus Fusarium sp. of Crocus sativus, BMR Microbiol. 2, 1-4.

[6] Y. Luo, P. Wang, G. Chen and L. Wen (2016). Study on the secondary metabolites from the endophytic fungus (CSL-13) of Crocus sativus L, Guangdong Chem. Indust. 43, 14, 39.

[7] I. H. Hwang, Y. S. Che, D. C. Swenson, J. B. Gloer, D. T. Wicklow, S. W. Peterson and P. F. Dowd (2016). Haenamindole and fumiquinazoline analogs from a fungicolous isolate of Penicillium lanosum, J. Antibiot. 69, 631-636.

[8] S. Limbadri, X. W. Luo, X. P. Lin, S. R. Liao, J. F. Wang, X. F. Zhou, B. Yang and Y. H. Liu (2018). Bioactive novel indole alkaloids and steroids from deep sea-derived fungus Aspergillus fumigatus SCSIO 41012, Molecules 23, 2379.

[9] R. H. Jiao, S. Xu, J. Y. Liu, H. M. Ge, H. Ding, C. Xu, H. L. Zhu and R. X. Tan (2006). Chaetominine, a cytotoxic alkaloid produced by endophytic Chaetomium sp. IFB-E015, Org. Lett. 8, 5709-5712.

[10] Y. Wang, Z. L. Li, J. Bai, Z. X. Chen, H. M. Hua and T. Liu (2017). Isolation, identification and antitumor activity of secondary metabolites from the marine-derived fungus Aspergillus fumigatus YK7, Chinese J. Med. Chem. 27, 382-387.

[11] P. Q. Huang, Z. Y. Mao and H. Geng (2016). Enantioselective total synthesis and structural revision of (-)-isochaetominine, Chinese J. Org. Chem. 36, 315-324.

[12] M. E. Rateb, I. Hallyburton, W. E. Houssen, A. T. Bull, M. Goodellow, R. Santhanam, M. Jaspars and R. Ebel (2013). Induction of diverse secondary metabolites in Aspergillus fumigatus by microbial coculture, RSC Adv. 3, 14444-14450.

[13] R. Liu, H. Li, J. X. Yang and Z. P. An (2018). Quinazolinones isolated from Aspergillus sp., an endophytic fungus of Astragalus membranaceus, Chem. Nat. Compd+. 54, 808-810.

[14] J. X. Peng, T. Lin, W. Wang, Z. H. Xin, T. J. Zhu, Q. Q. Gu and D. H. Li (2013). Antiviral alkaloids produced by the mangrove-derived fungus Cladosporium sp. PJX-41, J. Nat. Prod. 76, 1133-1140.

[15] Clinical and Laboratory Standards Institute (2012). Methods for dilution antimicrobial susceptibility tests for bacteria that grow aerobically; approved standard-ninth edition, Chin. J. Lab. Med. 32, 1-90.

[16] C. X. Jiang, J. Li, J. M. Zhang, X. J. Jin, B. Yu, J. G. Fang and Q. X. Wu (2019). Isolation, identification, and activity evaluation of chemical constituents from the soil fungus Fusarium avenaceum SF-1502 and endophytic fungus Fusarium proliferatum AF-04, J. Agric. Food Chem. 67, 1839-1846.

[17] C. Sun, H. Wang and X. X. Peng (2001). Study on the antibacterial activity of the peptide antibioticapidaecin against some plant bacterial pathogens and its toxicity against tobacco protoplast, Acta Phytopathol. Sinica 31, 275-279.

[18] G. R. Jachak, P. R. Tharra, P. Sevelda and J. Svenda (2021). Stereocontrolled synthesis of pseurotin $A_{2}$, J. Org. Chem. 86, 11845-11861. 
A new alkaloid from Crocus sativus

[19] T. Yamada, M. Oshima, K. Yuasa, T. Kikuchi and R. Tanaka (2016). Assignment of the CD cotton effect to the chiral center in pseurotins, and the stereochemical revision of pseurotin $\mathrm{A}_{2}$, Mar. Drugs 14, 74.

[20] F. Z. Wang, D. H. Li, T. J. Zhu, M. Zhang and Q. Q. Gu (2011). Pseurotin $A_{1}$ and $A_{2}$, two new 1-oxa-7azaspiro[4.4]non-2-ene-4,6-diones from the holothurian-derived fungus Aspergillus fumigatus WFZ-25, Can. J. Chem. 89, 72-76.

$$
\begin{gathered}
\text { A } \\
\text { publications } \\
\text { (C) } 2022 \text { ACG Publications }
\end{gathered}
$$

